Abstracted/indexed in Academic Search Complete, Agroforestry Abstracts, Asia Journals Online, Bangladesh Journals Online, Biological Abstracts, BIOSIS Previews, CAB Abstracts, Current Abstracts, Directory of Open Access Journals, EMBASE/Excerpta Medica, Google Scholar, HINARI (WHO), International Pharmaceutical Abstracts, Open J-gate, Science Citation Index Expanded, SCOPUS and Social Sciences Citation Index; ISSN: 1991-0088

\title{
Phytochemical characterization of phenolics by LC-MS/MS and biological evaluation of Ajuga orientalis from Turkey
}

\author{
Fatih Göger'1, Yavuz Bülent Köse ${ }^{2}$, Gamze Göger ${ }^{1}{ }^{3}$ and Fatih Demirci ${ }^{1}$, 4 \\ ${ }^{1}$ Department of Pharmacognosy, Faculty of Pharmacy; 2Department of Pharmaceutical Botany, Faculty of Pharmacy; \\ ${ }^{3}$ Graduate School of Health Sciences; ${ }^{4}$ Faculty of Health Sciences, Anadolu University, Eskişehir 26470, Turkey.
}

\begin{tabular}{|c|c|}
\hline \multicolumn{2}{|l|}{ Article Info } \\
\hline $\begin{array}{l}\text { Received: } \\
\text { Accepted: } \\
\text { Available Online: }\end{array}$ & $\begin{array}{l}27 \text { May } 2015 \\
29 \text { June } 2015 \\
\text { 15 July } 2015\end{array}$ \\
\hline \multicolumn{2}{|c|}{$\begin{array}{l}\text { DOI: } 10.3329 / \text { bjp.v10i3.23500 } \\
\text { Cite this article: }\end{array}$} \\
\hline $\begin{array}{l}\text { Göger F, Köse YB } \\
\text { F. Phytochemical } \\
\text { phenolics by LC-1 } \\
\text { cal evaluation of } \\
\text { Turkey. Banglades } \\
\text { 10: 639-44. }\end{array}$ & $\begin{array}{l}\text { I G, Demirci } \\
\text { terization of } \\
\text { and biologi- } \\
\text { rientalis from } \\
\text { irmacol. 2015; }\end{array}$ \\
\hline
\end{tabular}

\begin{abstract}
The aim of this study was to reveal the phytochemical constituents, antioxidant and antimicrobial activity of Ajuga orientalis. According to the antimicrobial results, the methanol extract of $A$. orientalis showed a MIC value of $312.5 \mu \mathrm{g} / \mathrm{mL}$ against the tested pathogenic bacterial strains. Anticandidal activity of extract was found as $156.3 \mu \mathrm{g} / \mathrm{mL}$ both against Candida albicans and C. parapsilosis strains. Whereas the extract was more effective against $C$. tropicalis with the MIC value of $78.1 \mu \mathrm{g} / \mathrm{mL}$. The in vitro DPPH radical scavenging activity of the extract was determined as $\mathrm{IC}_{50}=0.4 \pm 0.02 \mathrm{mg} / \mathrm{mL}$ whereas the standard BHT $\mathrm{IC}_{50}$ was $0.01 \pm 0.00 \mathrm{mg} / \mathrm{mL}$. Trolox Equivalent Antioxidant Capacity (TEAC) of extract was determined $1.3 \mathrm{mM}$ TEAC, while BHT, 1.9 mM TEAC.
\end{abstract}

\section{Introduction}

Ajuga L. is one of the largest genera of the Lamiaceae family with 301 species all over the world. In flora of Turkey, Ajuga is represented by 13 species and 23 taxa (Güner et al., 2012). Ajuga has some traditional therapeutic uses such as diuretic, antipyretic, tonic, diaphoretic and astringent in Turkey (Baytop, 1984). Ajuga species are used in traditional medicine all over the world against some illness such as gout, rheumatism, malaria, asthma and gastrointestinal diseases and have antibacterial, antitumor (Ben Jannet et al., 2006; Chen et al., 1996; Israili and Lyoussi, 2009, Setif, 2011), neuroprotective effects (Guo et al., 2011), anti-inflammatory and antioxidant (Makni et al., 2013; Turkoglu et al., 2010) activities among others biological effects.

Ajuga genus contains many important bioactive compounds like anthocyanins, diterpenoids, sterols, ionones, iridoids, phenylethanol and flavonoid glycosides (Maria et al, 1997, Chen et al., 1996; Shimomura et al., 1987; Terahara et al., 2001; Akbay et al., 2003).

Essential oil composition of $A$. orientalis was investigated and main compounds were germacren D $(24.7 \%), \beta$ -cubaben (18.3\%) and $\beta$-caryophyllene (16.9\%) (Sajjadi and Ghanadi, 2004).

Even though several bioactive compounds have been well studied on some Ajuga species, there is not enough data on phytochemical and biological activities for $A$. orientalis. To the best of our knowledge, this is the first report on determination of the major phenolic compounds, antioxidant activity and antimicrobial properties of the methanol extract of $A$. orientalis.

\section{Materials and Methods}

\section{Chemicals}

All antimicrobial agents, Mueller Hinton II broth and RPMI medium were purchased from Sigma-Aldrich Chemical Co (St. Louis, MO). Solvents were used analytical grade.

\section{Plant material and preparation of the extract}

A. orientalis was collected during flowering stage from Bursa, Turkey [A2 (A) Bursa: Bursa, Uludağ,1773 m, 19.6.2008, K 40006 ' 23.3" D 290 08' 11.1']. 


\section{Microbial strains}

The antimicrobial activities of the extract were tested against a panel of microbial strains, including: Escherichia coli NRRL B3008, Staphylococcus aureus ATCC 6538, Salmonella typhimurium ATCC 13311, Bacillus cereus NRRL B-3711, Candida albicans ATCC 90028, C. tropicalis ATCC 1369 and C. parapsilosis ATCC 22019.

\section{Determination of Minimum Inhibitory Concentration (MIC)}

The MIC values of the strains were determined by broth microdilution methods (CSLI, 2006, 2008). The methanol extract of $A$. orientalis was examined against a panel of seven different human pathogenic bacteria and Candida strains using the microdilution method according to CSLI method compared with standard antimicrobial agents. Methanol extract of $A$. orientalis was studied between [1250-2.44 $\mu \mathrm{g} / \mathrm{mL}$ ] for MIC and the antimicrobial standard agents ampicillin, tetracycline, ketoconazole (64-0.125 $\mu \mathrm{g} / \mathrm{mL}$ ) and oxiconazole (16$0.03 \mu \mathrm{g} / \mathrm{mL}$ ) were prepared in dimethyl sulfoxide (DMSO) and water.

The extract $(100 \mu \mathrm{L})$ was added to wells of row A, while the remaining wells in rows $B$ to $H$ received $50 \mu \mathrm{L}$ of cation adjusted Mueller-Hinton Broth-2 (MHB-2). Bacterial suspensions were grown overnight in double strength broth and were standardized to $10^{5} \mathrm{cfu} / \mathrm{mL}$ for bacteria. Each bacterial suspension $(50 \mu \mathrm{L})$ was added to the appropriate well. All Candida strains were inocula -ted on Patoto Dextrose Agar (PDA) prior the experiments at $35^{\circ} \mathrm{C}$. After incubation grown microorganisms were inoculated sterile saline \%0.85. And then standardized using a turbitometer (Biosan) (McFarland No: 0.5$)$ to $5 \times 10^{3} \mathrm{cfu}$ per well in RPMI medium under sterile conditions. Serial dilution series were prepared in $100 \mu \mathrm{L}$ RPMI medium with an equal amount of the test samples. After serial dilution $100 \mu \mathrm{L}$ each microorganism suspension was pipetted into each well and incubated at $35^{\circ} \mathrm{C}$ for 24 hours. Positive growth controls (to assess the presence of turbidity) were performed in wells not containing antimicrobial agents. In addition, negative growth control (medium) was applied in 96-well plate. After incubation at $35^{\circ} \mathrm{C}$ for 24 hours the first well without turbidity was determined as the MIC $(\mu \mathrm{g} / \mathrm{mL})$.

\section{Antioxidant activity (total phenolics)}

Total phenols were estimated as gallic acid equivalents (GAE), expressed as mg gallic acid/g extract (Singleton Vernon et al., 1999).

\section{TEAC assay (Trolox Equivalent Antioxidant Capacity)}

This test measures the ability of a compound to scavenge the ABTS (2,2'-azinobis-(3-ethyl-benzothiazoline6-sulfonate) radical in comparison to antioxidant activity of trolox which is a water-soluble form of vitamin E, used as a standard. The blue-green ABTS radical was formed through the reaction of $7 \mathrm{mM}$ ABTS with 2.5 $\mathrm{mM}$ sodium persulfate $\left(\mathrm{Na}_{2} \mathrm{~S}_{2} \mathrm{O}_{8}\right)$ in the dark at room temperature for 12-16 hours before use. ABTS solution was diluted with ethanol to a final absorbance of $0.7-0.8$ at $734 \mathrm{~nm} .10 \mu \mathrm{L}$ portion of the sample was added to $990 \mu \mathrm{L}$ of ABTS solution, and the reduction in absorbance was measured $1 \mathrm{~min}$ after addition of trolox up to 40 min after addition of the extract. The stock solution of trolox $(2.5 \mathrm{mM})$ was prepared in ethanol. Absorbance was measured on a UV/spectrophotometer (Papandreou et al., 2006).

\section{1,1-Diphenyl-2-picrylhydrazyl (DPPH) radical scavenging activity}

Serial dilutions were prepared with the stock solutions $(4 \mathrm{mg} / \mathrm{mL})$ of the extract to get the half concentration of previous one. Diluted solutions were added with $\mathrm{DPPH} \cdot($ equal amounts). After $30 \mathrm{~min} \mathrm{UV}$ absorbance was recorded at $517 \mathrm{~nm}$. The experiment was performed in triplicate for extract and positive standard control, BHT (butylated hyroxytoluene). The average of the absorption was noted for each concentration. The percentage inhibition was calculated using $\mathrm{Eq} 1$. The $\mathrm{IC}_{50}$ value, which is the concentration of the test material that inhibits $50 \%$ of the free radical concentration, was calculated as $\mathrm{mg} / \mathrm{mL}$ using Sigma Plot statistical program (Kumarasamy et al., 2007).

Percentage Inhibition $=$

$$
\left[\frac{(\mathrm{Abs} \text { control }-\mathrm{Abs} \text { sample })}{\mathrm{Abs} \text { control }}\right] x 100
$$

Equation 1

\section{Phenolic compound determination}

Experiments were performed with a Shimadzu 20A HPLC system coupled to an Applied Biosystems 3200 Q -Trap LC- MS/MS instrument equipped with an ESI ion source used in the negative ionization mode. Separations were performed on an ODS $150 \times 4.6 \mathrm{~mm}$, i.d., 3 $\mu \mathrm{m}$ particle sizes, octadecyl silica gel analytical column operating at $40^{\circ} \mathrm{C}$ at a flow rate of $1 \mathrm{~mL} / \mathrm{min}$.

Powdered dried herbal parts of A. orientalis were macerated with methanol $70 \%$ at $25^{\circ} \mathrm{C}$ for 24 hours. After evaporation of the methanol part, the aqueous part freeze-dried and the dry extract was used in all experiments.

\section{Results and Discussion}

An antioxidant activity generally occurs a hydrogen donating procedure. Phenolic acids and flavonoids are well known hydrogen donating agents due to their high PKa values. Determination of the total phenol com- 


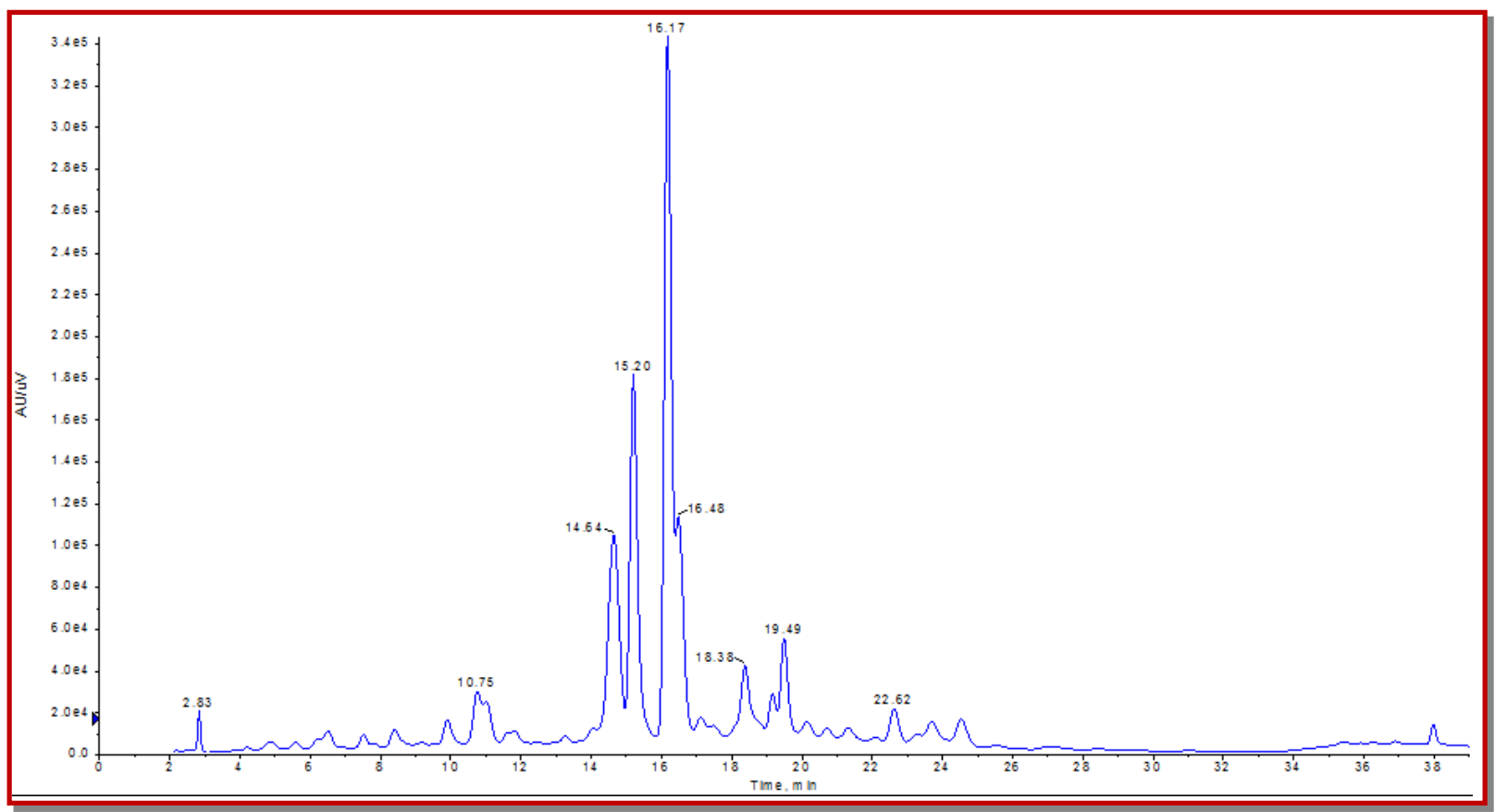

Figure 1: Ajuga orientalis LC chromatogram at $320 \mathrm{~nm}$

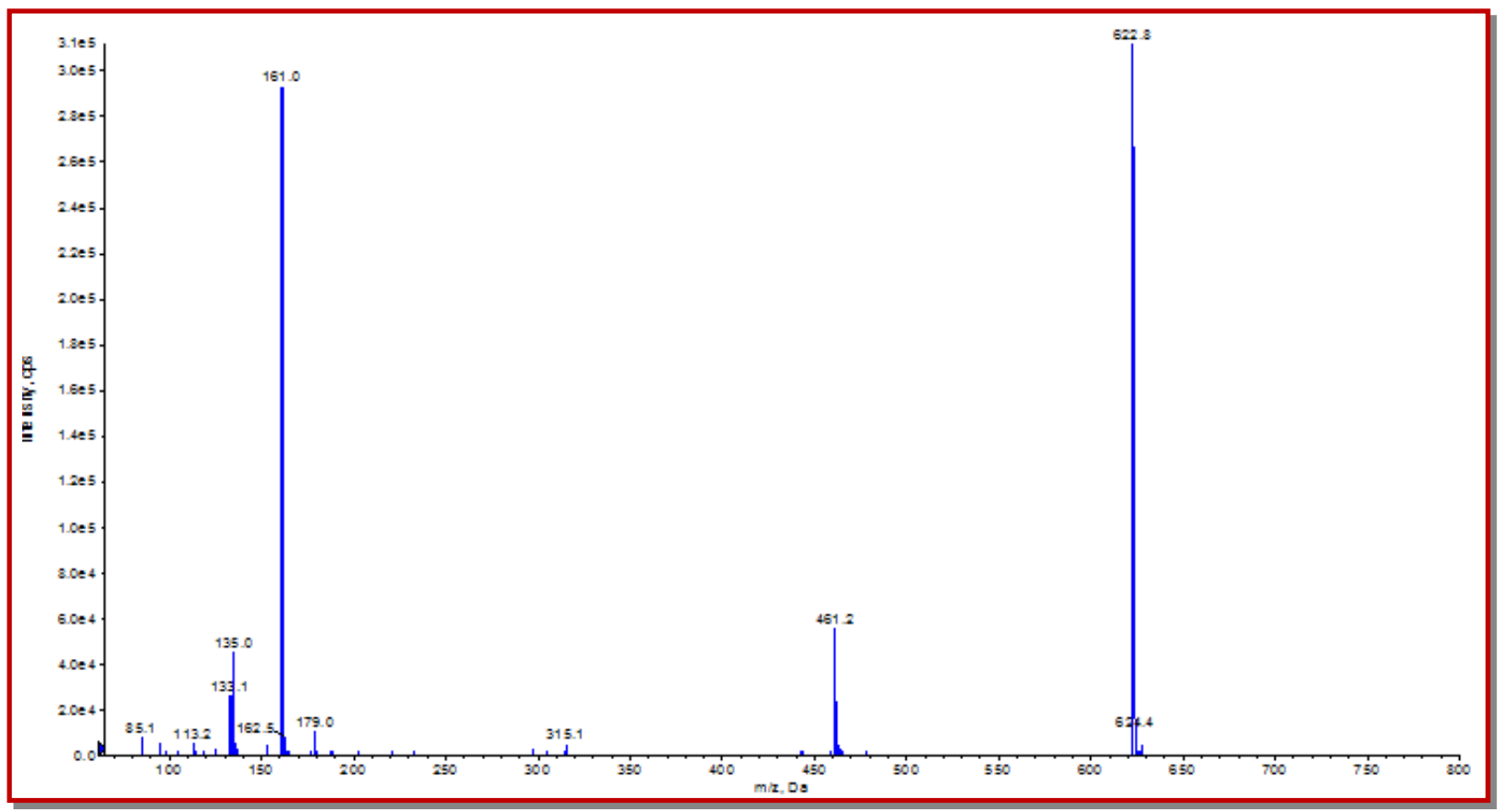

Figure 2: Mass spectrum of compound 5: verbascoside

pounds provides preliminary information about antioxi -dant activity results. The more total phenolic compounds means the more antioxidant activity.

According to results, extract of $A$. orientalis showed similar amount of gallic acid equivalent total phenol content in $1 \mathrm{~g}$ methanol extract. A. orientalis: $32 \mathrm{mg}$ GAE/g ext.

According to the identification of phenolic profile by
LC-MS/MS (Table I) 9 compounds were determined (Figure 1).

Compound 1Rt $=2.8$ co-eluted with $[\mathrm{M}-\mathrm{H}]$-molecular ions at m/z 195 (galactonic acid or gluconic acid) and $\mathrm{m} / \mathrm{z} 341$ (disaccharide like sucrose). High absorbance at $280 \mathrm{~nm}$ must be related to gradient changing of mobile phase. Product ions of $\mathrm{m} / \mathrm{z} 341$ similar with caffeoyl glucose fragments $(\mathrm{m} / \mathrm{z} 179, \mathrm{~m} / \mathrm{z} 161)$ but it is not 


\begin{tabular}{|c|c|c|c|c|c|}
\hline \multicolumn{6}{|c|}{ Table I } \\
\hline \multicolumn{6}{|c|}{ Compounds determined with LC-MS/MS } \\
\hline No. & Compound & Rt & $(\mathrm{M}-\mathrm{H})$ & Fragments & Reference \\
\hline 1 & Galactonic acid & 2.8 & 195 & $177,159,129,11$ & Nist 14 \\
\hline 2 & Ascorbic acid & 9.8 & 175 & 115 & Nist 14 \\
\hline 3 & Luteolin glucuronide derivative & 14.6 & 513 & $487,461,285,179,135$ & (Cvetkovikj et al., 2013) \\
\hline 4 & Echinacoside & 15.4 & 785 & $623,461,161$ & (Mitreski et al., 2014) \\
\hline 5 & Verbascoside & 16.2 & 623 & $461,315,161$ & (Mitreski et al., 2014) \\
\hline 6 & Forsythoside A & 16.5 & 623 & $461,315,161$ & (Guo et al., 2007; Mitreski et al., 2014) \\
\hline 7 & Castanoside A & 18.5 & 799 & 623,461 & (Mitreski et al., 2014) \\
\hline 8 & $\begin{array}{l}\text { 4"-O-methylisoscutellarein 7-O- } \\
\text { allosyl(1-2)glucoside }\end{array}$ & 19.2 & 623 & $461,315,161,135$ & (Petreska et al., 2011) \\
\hline 9 & Leucoseptoside A & 19.6 & 637 & 461,175 & (Mitreski et al., 2014) \\
\hline
\end{tabular}

possible to determine a caffeoyl glucose molecule at this retention time. Other fragments of galactonic acid can be seen in Table I.

Compound 2 was identified as ascorbic acid according to Nist 14 MS/MS library and comparison with authentic standard's fragmentation patterns.

Compound 3Rt $=14.6$ displayed $[\mathrm{M}-\mathrm{H}]^{-}$ion at $\mathrm{m} / \mathrm{z} 513$ and a base peak ion at $\mathrm{m} / \mathrm{z} 461$ further fragmentation showed several ions at $\mathrm{m} / \mathrm{z}$ 487, 461, 285 (most probably a luteolin), 179 and 135 . Following fragmentation of $\mathrm{m} / \mathrm{z} 461$, it was found as similar with luteolin glucuronide. However, compound 6 was exhibited 26 amu higher than luteolin glucuronide so this compound was labeled as luteolin glucuronide derivative.

Compound $4 \mathrm{Rt}=15.4$ displayed $[\mathrm{M}-\mathrm{H}]^{-}$ion at $\mathrm{m} / \mathrm{z} 785$ yielded a base peak ion at $\mathrm{m} / \mathrm{z} 623$ due to the loss of a hexose (or caffeoyl) moiety, the same loss of base peak ion was led to form ion at $\mathrm{m} / \mathrm{z} 461$. Other fragmentation corresponding with cinnamic acids, m/z 179 and 161 , was also observed. The compound was identified as echinacoside by compression to compound previously reported (Petreska et al., 2011).

Two compound, compound 5 (Figure 2) and 6 were coeluted at $\mathrm{Rt}=16.2$ and $\mathrm{Rt}=16.5$ with a same deprotonated molecular ion at $\mathrm{m} / \mathrm{z} 623$ which showed same fragmentation pattern. Both of the spectrums yielded $\mathrm{m} / \mathrm{z} 461$ owing to loss of a caffeoyl moiety (-162) and $\mathrm{m} / \mathrm{z} 315$ due to the loss of a rhamnose unit (-146). Caffeoyl part of the compounds were also observed at m/z 179 and further fragmentation at m/z 161 and 135. Compound 5 at RT 16.2 was determined as verbascoside whereas compound 6 at $\mathrm{Rt}=16.5$ was identified as fosythoside A using similar mass spectrum and chromatographic separation of previously reported data (Guo et al., 2007; Mitreski et al., 2014).

Compound $7 \mathrm{Rt}=18.5$ showed $[\mathrm{M}-\mathrm{H}]^{-}$ion at $\mathrm{m} / \mathrm{z} 799$ its MS/MS spectrum yielded two main fragments at $\mathrm{m} /$ z 623 (loss of a feruloyl, -176) and 461 (loss of a caffeoyl moity). This compound was identified as castanoside A according to previous data (Mitreski et al., 2014).

Compound 8 showed MS fragmentation characteristic of verbascoside and forsythoside A. Pseudomolecular ion at m/z 623 and its MS2 experiment yielded in several ions at $\mathrm{m} / \mathrm{z} 461,315,161$ and 135 . According to previously published data (Petreska et al., 2012) the compound, eluted after verbascoside and forsythoside A, with the same molecular weight is 4"-O-methylisoscutellarein 7-O-allosyl(1-2)glucoside. These data sugges -ted that compound could be identified tentatively as 4"-O-methylisoscutellarein 7-O-allosyl(1-2)glucoside.

Compound 9 showed $[\mathrm{M}-\mathrm{H}]^{-}$molecular ion at $\mathrm{m} / \mathrm{z} 637$ in MS2 spectrum a ferruloyl break at $\mathrm{m} / \mathrm{z} 461$ and the ferruloyl part at $\mathrm{m} / \mathrm{z} 175$ was also observed. This compound was labeled as leucoptoside A according to literature data (Mitreski et al., 2014; Petreska et al., 2011).

$\mathrm{DPPH} \cdot$ is a radical that gives maximum absorption at $517 \mathrm{~nm}$ in alcoholic solutions because of its intense purple color. The color of radical converts pale yellow if neutralized via an antioxidant compound. DPPH radical was used for determination of the radical scavenging antioxidant potential of $A$. orientalis extract. The extract radical scavenging activity was not effective as a positive control standard BHT. $\mathrm{IC}_{50}$ value of the extract was $0.4 \pm 0.02 \mathrm{mg} / \mathrm{mL}$ and the positive control of BHT $0.01 \pm 0.00 \mathrm{mg} / \mathrm{mL}$.

The calibration curve of trolox that is water soluble analog of vitamin $\mathrm{E}$ is used in the quantification. A radical form of ABTS is used as an indicator for evaluation of the antioxidant activities. This radical occurs after treatment of the non-radical ABTS salt with potassium persulfate after 16 hours. Alcoholic solution of radical gives maximum absorption at $734 \mathrm{~nm}$ owing to its green color. Green color of the radical converts to colorless and the absorption reduces if it encounters with antioxidant compound. In this test high TEAC 
Table II

\begin{tabular}{|c|c|c|c|c|c|}
\hline \multicolumn{6}{|c|}{ Table II } \\
\hline \multicolumn{6}{|c|}{ Minimum Inhibitory Concentrations (MIC, $\mu \mathrm{g} / \mathrm{mL}$ ) } \\
\hline Microorganisms & $\begin{array}{c}\text { Ajuga orientalis } \\
\text { extract }\end{array}$ & Ketoconazole & Oxiconazole & Ampiciline & Tetracycline \\
\hline Escherichiacoli NRRL B-3008 & 312.5 & - & - & 4 & 4 \\
\hline Staphylococcus aureus ATCC 6538 & 312.5 & - & - & 2 & 2 \\
\hline Salmonella typhimurium ATCC 13311 & 312.5 & - & - & 2 & 2 \\
\hline Bacillus cereus NRRL B-3711 & 312.5 & - & - & 0.5 & 0.5 \\
\hline Candida albicans ATCC 90028 & 156.25 & 1 & 4 & - & - \\
\hline Candida tropicalis ATCC 1369 & 78.12 & 0.5 & 2 & - & - \\
\hline Candida parapsilosis ATCC 22019 & 156.25 & 2 & 2 & - & - \\
\hline
\end{tabular}

values shows high antioxidant activity results. ABTS • + radical scavenging and DPPH radical scavenging effect showed a high correlation with each other. The extract at $1 \%$ concentration, showed ABTS $\bullet+$ radical scavenging effect. But the extract was not found as effective as standard BHT. TEAC values were found $1.3 \mathrm{mM}$ for extract and $1.9 \mathrm{mM}$ for BHT.

Oxidative attack of free radicals is the reason for many chronic diseases. Natural antioxidants such as flavonoids and phenolic acids help to protect human body from free radicals (Koolen et al., 2013). Antioxidant activity of this plant can be used as natural radical scavenger but not as good like as synthetic standard antioxidants. Determined phenolic compounds are the first reason of the antioxidant activities. Hydroxyl rich compounds is well known free radical scavengers. Obtained total phenolic compounds amount can be low for this plant material using this extraction procedure. However, high amount of hydroxyl groups of molecules that we determined showed moderate activity.

Discovering new antimicrobial agents are also important because of antimicrobial resistance of some microorganism. Synthetic antimicrobial agents are used in several years and today some of them are ineffective and researchers are focused on to investigate new natural antimicrobial agents.

Additionally phytochemical studies of the extract, in vitro antimicrobial activity was evaluated seven different strains in this study (Table II) using microdilution methods. A. orientalis extract exhibited antimicrobial action against all tested microorganisms, being more effective against yeasts than bacteria. The MIC was found at $312.5 \mu \mathrm{g} / \mathrm{mL}$ for Escherichia coli, Staphylococcus aureus, Salmonella typhimurium and Bacillus cereus. MIC value of $156 \mu \mathrm{g} / \mathrm{mL}$ for C. albicans and C. parapsilosis for the extract. Our results showed that $C$. tropicalis was the most sensitive strain for the extract $(\mathrm{MIC}=78.12 \mu \mathrm{g} / \mathrm{mL})$.

There have been some reports for antimicrobial activities belong to A. orientalis. Ali-Shtayeh et al (2013) found that extract of $A$. orientalis inhibited the growth of some acne-inducing bacteria and aerobic bacteria (Ali-
Shtayeh et al 2013). A. orientalis was also evaluated antifungal activity against Phytophthora capsici which is a pathogen fungus (Kiran et al, 2010).

As a result, the antimicrobial activity was determined the first time for A. orientalis extract, especially against Candida species. The extract can be used as an alternative natural prevention of Candida infections and candidal resistance.

\section{Acknowledgement}

This work was supported by the Anadolu University Research Funding (Project No.: BAP: 080307).

\section{References}

Akbay P, Calış I, Heilmann J, Sticher O. Ionone, iridoid and phenylethanoid glycosides from Ajuga salicifolia. Z Naturforsch. 2003; 58C: 177-80.

Ali-Shtayeh, MS, Al-Assali AA, Jamous RM. Antimicrobial activity of Palestinian medicinal plants against acne-inducing bacteria. Afr J Microbiol Res. 2013; 7: 2560-73.

Baytop T. Türkiyede bitkiler ile tedavi geçmişte ve bugün; İstanbul Üniversitesi. 1984.

Ben Jannet H, Chaari A, Bakhrouf A, Mighri Z. Structureantibacterial activity relationship of secondary metabolites from Ajuga pseudoiva Rob. leaves. Nat Prod Res. 2006; 203: 299-304.

Chen H, Tan RX, Liu ZL, Zhang Y, YangL. Antibacterial neoclerodane diterpenoids from Ajuga lupulina. J Nat Prod. 1996; 597: 668-70.

Clinical and Laboratory Standarts Institue (CLSI) 2006. Methods for dilution antimicrobial susceptibility tests for bacteria that grow aerobically, CLSI M7-A7, Clinical and Laboratory Standards Institute, 940 West Valley Road, Wayne, Pennsylvania, USA.

Clinical and Laboratory Standards Institute (CLSI). Reference method for broth dilution antifungal susceptibility testing of yeast, Approved standard. CLSI 27-A3. 3rd ed. PA, USA, 2008.

Cvetkovikj I, Stefkov G, Acevska J, Stanoeva JP, Karapandzova M, Stefova M, Kulevanova S. Polyphenolic characterization 
and chromatographic methods for fast assessment of culinary Salvia species from South East Europe. J Chromatogr A. 2013; 1282: 38-45.

Güner A, Aslan S, Ekim T, Vural M, Babaç M.Türkiye Bitkileri Listesi Damarlı Bitkiler. Nezahat Gökyiğit Botanik Bahçesi ve Flora Araştırmaları Derneği Yayını. İstanbul. 2012.

Guo H, Liu AH, Ye M, Yang M, Guo DA. Characterization of phenolic compounds in the fruits of Forsythia suspensa by high-performance liquid chromatography coupled with electrospray ionization tandem mass spectrometry. Rapid Commun Mass Spectrom. 2007; 215: 715-29.

Guo P, Li Y, Xu J, Liu C, Ma Y, Guo Y. Bioactive neo-clerodane diterpenoids from the whole plants of Ajugaciliata Bunge. J Nat Prod. 2011; 747: 1575-83.

Israili $\mathrm{ZH}$, Lyoussi B. Ethnopharmacology of the plants of genus Ajuga. Pakistan J Pharm. 2009; 224: 425-62.

Kıran ÖE, İlçim A, Dığrak, M. Antifungal activity against Phytophthora capsici leon which causes root neck burn in pepper around Kahramanmaras. Asian J Chem. 2010; 22:1; $468-74$.

Koolen HHF, Da Silva FMA, Gozzo FC, De Souza AQL, De Souza ADL. Antioxidant, antimicrobial activities and characterization of phenolic compounds from buriti Mauritia flexuosa L. by UPLC-ESI-MS/MS. Food Res Int. 2013; 512: $467-73$.

Kumarasamy Y, Byres M, Cox PJ, Jaspars M, Nahar L, Sarker SD. Screening seeds of some Scottish plants for free radical scavenging activity. Phytother Res. 2007; 217: 615-21.

Makni M, Haddar A, Kriaa W, Zeghal N. Antioxidant, free radical scavenging, and antimicrobial activities of Ajuga iva leaf extract. Int J Food Prop. 2013; 164: 756-65.

Maria C, Rodriguez, B, Bruno, M, Piozzi, F, Vassallo, N, Bondi, Maria L, Servettaz, O. Neo-clerodane diterpenoids from Ajuga australis and A. orientalis. Phytochemistry 1997; 45: 121-23.

Mitreski I, Stanoeva JP, Stefova M, Stefkov G, Kulevanova S. Polyphenols in representative Teucrium species in the flora of
R. Macedonia: LC/DAD/ESI-MS; profile and content. Nat Prod Commun. 2014; 92: 175-80.

Papandreou MA, Kanakis CD, Polissiou MG, Efthimiopoulos S, Cordopatis P, Margarity M, Lamari FN. Inhibitory activity on amyloid- $\beta$ aggregation and antioxidant properties of Crocus sativus stigmas extract and its crocin constituents. J Agr Food Chem. 2006; 5423: 8762-68.

Petreska J, Stefova M, Ferreres F, Moreno DA, Tomas-Barberan FA, Stefkov G, Gil-Izquierdo A. Potential bioactive phenolics of Macedonian Sideritis species used for medicinal mountain tea. Food Chem. 2011; 1251: 13-20.

Petreska Stanoeva J, Bagashovska D, Stefova, M. Characterization of urinary bioactive phenolic metabolites excreted after consumption of a cup of mountain tea Sideritis scardica using liquid chromatography-tandem mass spectrometry. Maced J Chem Chem Eng. 2012; 31: 2229-43.

Sajjadi SE, Ghannadi A. Volatileoilcomposition of the aerial parts of Ajugaorientalis L. from Iran. Z Naturforsh. 2004; 59c: 166-68.

Setif A. Antibacterial activity of extract of Ajuga iva and Teucrium polium. Adv Environ Bio. 2011; 52: 491-95.

Shimomura H, Sashida Y, Ogawa K. Iridoid glucosides and phenylpropanoid glycosides in Ajuga species of Japan. Phytochemistry 1987; 26: 1981-83.

Singleton Vernon L, Orthofer R, Lamuela-Raventos RM. Analysis of total phenols and other oxidation substrates and antioxidants by means of folin-ciocalteu reagent. Methods Enzymol. 1999; 299C: 152-78.

Terahara N, Callebaut A, Ohba R, Nagata T, Ohnish Kameyama M, Suzuki M. Acylated an thocyanidins 3sophoroside-5-glucosides from Ajuga reptans flowers and the corresponding cell cultures Phytochemistry 2001; 58: 493500 .

Turkoglu S, Turkoglu I, Kahyaoglu M, Celik S. Determination of antimicrobial and antioxidant activities of Turkish endemic Ajuga chamaepitys L. Schreber subsp. euphratica PH Davis Lamiaceae. J Med Plant Res. 2010; 413: 1260-68. 